\title{
Article
}

\section{A Century of British Readings of America Through American Football: From the Fin de Siècle to the Super Bowl}

\author{
Adams, lain Christopher \\ Available at http://clok.uclan.ac.uk/18739/ \\ Adams, lain Christopher (2017) A Century of British Readings of America \\ Through American Football: From the Fin de Siècle to the Super Bowl. The \\ International Journal of the History of Sport . pp. 1-20. ISSN 0952-3367
}

It is advisable to refer to the publisher's version if you intend to cite from the work. http://dx.doi.org/10.1080/09523367.2017.1304917

For more information about UCLan's research in this area go to http://www.uclan.ac.uk/researchgroups/ and search for < name of research Group>.

For information about Research generally at UCLan please go to http://www.uclan.ac.uk/research/

All outputs in CLoK are protected by Intellectual Property Rights law, including Copyright law. Copyright, IPR and Moral Rights for the works on this site are retained by the individual authors and/or other copyright owners. Terms and conditions for use of this material are defined in the policies page. 


\title{
'A Century of British Readings of America through American Football: From the Fin de Siècle to the Super Bowl'
}

Iain Adams

International Football Institute, University of Central Lancashire, Preston, UK

\begin{abstract}
This paper examines the development of American football and the Super Bowl in the British imagination utilizing data from the British press. Divergent images of America have been present for centuries in British minds, and American football became intertwined with these images in the nineteenth-century. Initially presented as a brutalized version of British varieties of football, once American football was seen live in Great Britain and it became a familiar subject on newsreels some commentators interpreted it as a spectacle and a synonym for American life--modern, exciting, fast and fun. Others viewed it as a threat that could undermine the British cultural heritage. The regular broadcasting of the NFL by Channel 4, including the Super Bowl live, was a watershed with the game swiftly gaining audience numbers whilst English association football was in a dour period. The increased popularity resulted in more media coverage, including negative images of unbridled capitalism, fixed games and drug use. By the 1990s, audience numbers declined as English football was rehabilitated and American popularity waned, mainly through unpopular foreign policies. Today, many Britons regard watching the Super Bowl in the same way as a trip to Disney, a one-day holiday to a 'foreign' culture.
\end{abstract}

\section{Key Words}

American football, Super Bowl, United Kingdom, Newsreel, Sporting Imagination

'It is bad enough to agree to have cruise missiles here in England, but to have American football as well must surely herald the end of our ancient and revered civilisation.'

America has fascinated the British for over five hundred years. As scholars of British visions of America have observed, Britain has been 'assailed with two quite distinct images of America'. These divergent views were established in the colonial period by settlers, typically from the lower economic classes, and visitors, usually middle or upper class. The former enjoyed greater economic opportunities and political freedom away from hierarchical Britain, but the latter, enjoying the privileges of British society, 
portrayed the American colonies as a philistine society plagued by both natural and human dangers. ${ }^{2}$

By the late nineteenth century, America had been transformed from an agrarian colonial society into an independent industrial and urban nation that was beginning to politically and economically challenge European countries and their empires. The shared language, cultural ties and historical traditions ensured the impact of the United States (US) was greater on Britain than elsewhere in Europe and British interest in America blossomed. ${ }^{3}$ Britons relied upon the burgeoning print media for information, and newspapers catering to all social classes regularly featured America and American life as settlers and travellers inevitably recorded their experiences. In an 1869 letter to possible emigrants, Daniel Archer, a settler who had landed in New York in 1850, wrote:

America, with all its difficulties and defects, is the most prosperous and highly-favoured country to emigrate to on the habitable globe. There can be no place where the poor working-man can so easily obtain subsistence for himself and family, and where the intellect of all classes is, or may be, highly cultivated, or where man is more highly appreciated according to his real value. Success is certain to the man of energy and good repute. ${ }^{4}$

Others, defending the culture they enjoyed, depicted British society as led by cultured gentlemen whereas America was dominated by a boorish middle class; 'robber barons' rapaciously exploiting their workers leaving inner cities as areas of unemployment and poverty whilst producing a shallow and degraded society in which materialism subsumed high culture. ${ }^{5}$ The US was seen as the crucible of a mass culture characterized by democratic mediocrity, barbarism, and scant respect for tradition rather than the progressive processes of industrialization and urbanization. British critics of the US conveyed this viewpoint through stories of violence, corruption, and poverty. As the 
English writer Rudyard Kipling once quipped: 'I have struck a city - a real city - and they call it Chicago ... Having seen it, I urgently desire never to see it again. It is inhabited by savages. ${ }^{6}$

\section{The Image of American Football, 1887-1909}

This milieu explains the tone of British newspaper reports that a meeting of the InterCollegiate Football Association had amended American football rules due to the 'unanimity among the representatives present in expressing the opinion that the old roughness and brutality of the game should be done away with. ${ }^{7}$ Over the following two decades, most British press stories concerning American football focused on its brutality. In response to concern about unruliness in rugby, a Welsh newspaper commented that 'rugby footballers in England, though sometimes blamed for rough play, must be lamblike in their actions compared to a typical American footballer. The football reports of American newspapers are a perfect catalogue of horrors.' Frequent accounts of American football's 'butcher's bill', outlining the fatalities and serious injuries occurring, were promulgated. ${ }^{8}$ Elite university games were no exception. The 1894 Harvard-Dartmouth match was 'brutal and cowardly,' one report noted, adding how the object of the game seemed to be 'knock out' the opposition. After watching the teams 'lining out' with each man going for the man opposite and bringing him down 'by any means in his power', the correspondent concluded:, 'I left disgusted with the exhibition. Brute force was accepted as a substitute for skill and science, and there was little, if any, real sporting spirit shown by the players'. ${ }^{9}$ Another story in the British press marvelled that the number of casualties sustained in traditional Thanksgiving Day games 'was enormous, and the recent match between Yale and Harvard almost assumed the proportions of a small massacre ... To return with his shield or on it would almost seem to be required as a motto by the modern footballer.' 10 
British newspapers reported other negative aspects of the American game. As British conservatives battled to maintain amateurism in sport, they insisted that the evils of professionalism had already penetrated into American university sport. The Manchester Guardian recorded that the 1893 Yale-Princeton match had brought in $\$ 50,000$ in gate receipts and that these profits were being used to recruit students solely for their football talents. ${ }^{11}$ Positive views were occasionally offered. In 1895, the US defender of American amateurism Caspar Whitney reported the impressions he garnered on his pilgrimage to study English sport. Whitney expressed disappointment with English football although he could identify where American 'scientifically developed play' originated:

Our own American university game is so superior in point of scientific preparation and skilful play that I felt exactly as though, for instance, I had gone to see the Princeton 'Varsity team, and, instead, the scrub slaves had been brought out for my entertainment. I could not help the feeling, as I stood on the side lines, that I was a spectator of an undeveloped game - that there were so many ignored opportunities. One who knows American football must, on first seeing a Rugby Union match, feel he is watching an elementary game. ${ }^{12}$

At the end of the nineteenth century, despite sporadic efforts to portray American football as a product of a modern, sophisticated, and cultured society, the overarching British portrayal depicted vulgar Americans remaking a tough, manly British sport into a degenerate game--the product of a coarse and deteriorating culture. ${ }^{13}$

\section{The Game Arrives, 1910-1918}

In April 1910, the British press informed the public that American football rules had been materially changed again to increase safety, 'but without eliminating the 
spectacular side of the game'. However, in November of that year, British newspaper readers were informed about the death of West Virginia University quarterback Rudolph Munk from 'concussion of the brain'. ${ }^{14}$ Five days later, the media announced that an American football match was to be played in London by the visiting US Navy's Atlantic Fleet. The USS Idaho of the fleet's Third Division, moored in the Thames estuary, had challenged the USS Michigan of the First Division lying at Portland. ${ }^{15}$ The press stressed that the initial challenge had been issued by wireless over a distance of approximately 130 miles, buttressing the view of America as a developing naval and technological power. Ultimately, a three match tournament was organised, starting with one game for the Third Division in London and a further match for the First Division in Weymouth, both on Thanksgiving. The winners were slated to meet for the fleet championship. The day before Thanksgiving, the newspapers revealed that the team representing the battleship Idaho would play the squad from the battleship Vermont at Crystal Palace. Reports promised that 'American sailors will appear on the field with a full complement of the necessary football "armour," including head-guards, shin-guards, and well-padded clothing. British reporters anticipated a keen display of their much-discussed American “College" game'. ${ }^{16}$

In light of the established image of American football, it is not surprising that the London Daily News account of the USS Vermont versus USS Idaho clash led with the headline: 'Nobody was killed at the American football match at the Crystal Palace yesterday'. The London correspondent observed that the game attracted widespread interest 'mainly because of its novelty to an English crowd, and partly because of the appalling casualty lists from the States that so frequently bring the American game into derision on the English side of the Atlantic.' The curious English crowd of 12,000 enjoyed 'a rousing struggle' which the Idaho won 19-0. ${ }^{17}$ The Times reported that the 
slippery ground, a greasy ball, and the ineptitude of the Vermont team had prevented an object lesson in American football, 'the first of the kind ever given in this country'. In the view of The Times, the majority of spectators left the American exhibition convinced that Rugby Union was 'superior in every respect, better to play, and better to watch'. The Times did admit that it was a clean match played with keenness and good humour and casualties were few and not serious. The London daily opined that the 'yearly "butcher's bill" of which so much is heard in the United States' must be the result of those who deliberately indulged in foul and brutal play. Nevertheless, even when played in a sporting spirit and to the letter of the laws, the game was rough. In fact, The Times contended that 'an ill-tempered game of Rugby football in the Celtic twilight is a Sunday school picnic in comparison.' The report concluded that the game was a:

Direct descendant of the all-in football of our ancestors (but we) shall stick to our preference despite the Crystal Palace object-lesson in an antiquarian pursuit, a fossilized form of football. But one must needs feel amazed and a little amused that the Americans should be playing $16^{\text {th }}$ century football in the $20^{\text {th }}$ century. Really it is rather unprogressive. ${ }^{18}$

In the next contest the USS Connecticut beat the USS Michigan at Weymouth, setting up a contest against the Idaho for the championship. In the lacklustre final, 'the only score was the winning try gained by the Idaho team.' The victory signalled the Idaho's band to make great demonstrations of enthusiasm. 'The hurricane-like tactics of the players is reflected in the attitude of the spectators, who follow the game with a nervous energy and vociferous enthusiasm which must be rather exhausting,' The Times marvelled. The game produced, from the vantage of elite London daily, 'an exhibition which, if to a great extent incomprehensible to the English football expert, was nevertheless interesting by reason of its mystery and contrast.' 19 
American football left Britain with the fleet until the outbreak of World War I (WWI) when sporting events began to be used for charity. In November 1915, two American teams played an American football match for the benefit of the Prince of Wales' and the Red Cross Funds during the Christmas holidays. ${ }^{20}$ Once the US joined the Allied cause and American troops began to arrive, charity matches were played around the country. Two US Navy units drew 0-0 at Stamford Bridge, Chelsea, in aid of the St. Dunstan's Blind Servicemen charity. The Times, after trying to explain the game's rules, concluded by describing the many 'concomitants, which we are accustoming ourselves to hear in many American games,' including the marching band, an airship, and dancing by spectators. In 1918, the Liverpool Hospital Cup final was held on the American Thanksgiving holiday at Goodison Park between the USS Leviathan and a team of engineers from the Knotty Ash American Army rest camp. The event featured the usual entertainment: the ship's band, organised cheering and displays, and a trophy presented by the Lord Mayor of Liverpool. ${ }^{21}$

Significantly more people, however were introduced to American football through a 45 second, silent, black and white Pathé newsreel of the Harvard-Yale game in 1916 than through charity gridiron contests in England. Although the newsreel did not include pre-match or half-time entertainments, the film narrative captured essential elements of pageantry of American football, including the vast crowd emphasized through an opening panning shot, the speed of the game revealed by a long distance view of a down, and the intensity of the action captured from a side-line camera. Audiences enjoyed a longer exposure in the comedy short Won by a Foot, released to good reviews in 1917, a year when over twenty million people a week went to the cinema. One critic labelled it 'a rattling comedy in which the remarkably strenuous American game of football was vividly illustrated' ${ }^{22}$ 
WWI irrevocably changed the relationship between Britain and America as the US realized its potential as a world power and Britain's self-confidence declined and a slow retreat from empire began. Significant numbers of British citizens must have wondered if the America portrayed on the cinema screen, in American novels and comics, and in American versions of team sports offered a better future. American football departed with the troops but significant numbers of the public had now either seen it, live or on film, or read match reports. The game was different, not British, but nevertheless an entertaining spectacle generating excitement. To many, this alternative version of football offering modernity, dynamism and fun represented a microcosm of the possibilities of American styles of life.

\section{The Interbellum}

Post-war, newspaper reports of American football declined, becoming mainly restricted to the results or 'sports in brief' columns. Occasionally, more detailed stories appeared with the press continuing to illuminate the differences between American football and British games. However, with the public having seen the game, the images of brutality and violence were curtailed and the sport as spectacle emphasised. In 1929, a syndicated story described attending a match in America:

Just as you cannot fool all the public all the time, so the game would not persist, nor enjoy its wonderful popularity, if it were not actually a great game ... the band and cheer leaders fan a flame, and thus when a sensational incident does occur, lo! One is on one's feet with the rest of them ... you too are yelling at lung limit, and what you are yelling, and why you are yelling, you don't quite know - nor do you care; you've been bitten by the football bug. ${ }^{23}$ 
The enthusiasm of the vast crowds was accentuated in the newsreels which, by the 1920s, were widely popular and audiences felt that no cinema programme was complete without them. ${ }^{24}$ Pathé showed the opening game of the 1921 season in a story entitled 'U.S.A. Some Game! ... the game, although a little more strenuous than ours, - attracts many "fans". The film sets the format for broadcasting American football to British audiences for the period, starting with an opening long shot of the action including the large stadium crowd, then cutting to a medium shot showing a fast-moving down, and then inter-cutting views of a happy boisterous crowd, including a smartly dressed band in this instance, followed by close-ups emphasising the power and intensity of the action. By 1929, the newsreels included the pre-game show as well. The newsreel of Notre Dame's 7-0 defeat of the Army highlights the vast crowd and the drilling cadets on the field with a group of male cheerleaders forming a pyramid. The Army-Navy game became an annual staple and followed the well-established format of an enticing title. In 1930, British audiences were heralded with 'Excitement! ... 100\% plus!!' The clip then presented pre-game shots of drilling army and navy cadets, and close-ups of players emphasizing their ruggedness in a similar manner to the heroes of Westerns of the period. Once the game starts the action is interspersed with close-ups of the excited cheering crowd and streamers being thrown into the air when a touchdown is scored. Outside of the areas where the cadets congregated, the cameras captured a high proportion of welldressed women. ${ }^{25}$

The newsreels also featured children's and prison football games, as well as women training and playing. The newsreel narratives stressed the modernity of the game through the training equipment in use, the precision manufacture of equipment, and even a clip of a scientist demonstrating a new helmet design by running head first into a brick wall. American football also introduced slow motion to British viewers. The 1926 Princeton 
victory over Harvard followed the standard format until an inter-title, 'Going for it "hammer and tongs ... in slow motion", emphasised the athleticism of a running back and the power of the tackling and blocking through slow-motion footage. ${ }^{26}$

While cinema audiences were declining from the 1917 peak, the 1920s and 1930s saw a steady growth in middle-class cinema goers although the most frequent customers were the young urban working-class, especially women. There was an accompanying increase in the proportion of American films shown and to many in the audiences America seemed glamorous, sophisticated and romantic; a 'Promised Land' away from their own dull jobs and financial struggles. British audiences copied clothing styles and saw the progenitors of rock music in films. A cinema correspondent observed:

The plain truth about the film situation is that the bulk of our picturegoers are Americanised to an extent that makes them regard a British film as a foreign film, and an interesting but more frequently irritating interlude to their favourite entertainment. They go to see American stars ... They talk America, think America, and dream America. We have several million people, mostly women, who for all intent and purposes are temporary American citizens. ${ }^{27}$

With the arrival of 'talkies' in 1929, the weekly audiences recovered reaching 18 million per week in 1930 and increased dramatically through World War II (WWII) to peak at 31 million in 1946. Throughout the 1920s, 1930s, and 1940s, American films dominated the screens with their stories of ambition, competition, conflict, tension, and moral and emotional intensity, and American football was integral to stories that showcased these themes in such films as The Freshman, Horse Feathers and Easy Living. ${ }^{28}$ Although live games had disappeared from Britain, the silver screen image of 
American football represented fun, speed, excitement and spectacle in a dynamic, wealthy, egalitarian and developing America.

The interwar period also intensified British critiques of American culture and influence. As travel improved, more writers crossed the Atlantic and the diverse opinions of America intensified. H.G. Wells, the prolific English writer, believed American influence would help the world be freer and more stable and J.B. Priestly, a social commentator, was impressed by the collective developments of 'The New Deal' whilst joining other critics in worrying that the worst of monopoly capitalism was fuelling a superficial and vulgar mass culture that could undermine Britain's cultural heritage. ${ }^{29}$ As the 1930's ended, a larger invasion by American mass culture approached.

\section{World War II}

Cinemas remained open throughout WWII and newsreels continued to show American football, even on the deck of the USS Wasp at sea. In 1940, Pathé introduced a story with consecutive titles, 'Exclusive!', 'Special Release!', 'The FIRST Newsreel subject ever presented in color', 'The Tournament of Roses - The Rose Bowl Game'. Stirring music accompanied the headline barrage. This story ran for nearly six and a half minutes and featured the Rose Parade with horsemen carrying the American flag, bikini clad girls waving from a float accompanied by wolf whistles on the sound track, marching majorettes, and the Grand Marshal in an open-topped car. The Rose Bowl game followed, utilizing the formula of interspersed takes of the action and the crowd, who, at half time, made a US flag by holding up coloured cards. In blacked-out and ration-book Britain, the event must have appeared highly glamorous, fun and seductive. The colour and mixed crowd of men and women would have made a vivid contrast to the male working-class throngs in dour football stadiums in Britain. ${ }^{30}$ 
In 1942, the first of three million American servicemen arrived and live games reemerged, often, once again, for charitable purposes. Despite having reported on the games of 1910 and 1918, The Times inaccurately asserted that 'the first game of American football ever to be seen in this country will be played at the White City Stadium on Saturday, May 8'. The match was in aid of the Red Cross Prisoners of War Fund and the teams competing were 'The Crimson Tide' and 'The Fighting Irish,' a field artillery unit and an engineering unit. The London daily announced that complete regulation equipment was to be worn, two US Army bands would attend, and there would be cheerleaders and reserved cheering sections for soldiers. On the morning of the game, The Times outlined the main features of the game, once again mistakenly asserting that the exercise was necessary because 'American football ... has often been seen on the films but never in the flesh in this country.' It noted that the game was being played as a gesture of gratitude for the hospitality shown to American troops in Britain and every attempt was being made to make the match like 'an inter-collegiate game back home.' The post-game story revealed that most non-American spectators thought there were too many delays, that the game was slow, 'almost, at times, to the point of becoming tedious', and that most British spectators missed a number of the finer points of the American version of football. Some spectators no doubt missed all of them. ${ }^{31}$

The game that stirred up the most media interest was the 'Tea Bowl' at the White City stadium in February 1944. This pitted a Canadian Army team, against a US Army team. The crowd of 30,000 had the additional entertainment of the Canadian pipe bands and a US army band. The first half was played under American rules and the second half under Canadian rules. The Canadians won 16-6 and the Americans demanded a rematch. A month later, the White City hosted the 'Coffee Bowl' in front of 50,000 people which the Americans won $18-0 .{ }^{32}$ 


\section{The Cold War}

At the end of WWII, as Britain's economy lay in ruins, America's position as the world's leading military and economic power was confirmed. In February 1946, Soviet premier Joseph Stalin announced that capitalism and imperialism made future wars inevitable and in March, British Prime Minister Winston Churchill delivered his speech in the USA asserting, "an iron curtain has descended across the continent". ${ }^{33}$ The American government committed itself to the defence of Europe and some 50,000 American service personnel remained in Britain.

The permanent basing of American troops meant that more American football was being played than ever before in Britain, although mainly out of the public eye on military bases. The United States Air Force in Europe (USAFE) established an American football league with a United Kingdom Sports Conference. Although newspaper coverage of American football declined, Pathé news continued their frequent film stories featuring the occasional professional game, the customary Army-Navy games, the Cotton and Rose Bowls, as well as intermittent oddities such as a 1958 feature of a women's water skiing team passing a football. ${ }^{34}$

In December 1952, the USAFE American football season championship match was played at Wembley. On the morning of the game, The Times reported that 'This afternoon promises to be full of astonishing sights and sounds - that is to British eyes and ears - as it will be unique for the Americans themselves. ${ }^{35}$ The programme featured massed bands, cheerleaders, drum majors and majorettes 'along with all the other concomitants of a football match of the first magnitude on the other side of the Atlantic.' The postgame story provided a summary of the match and noted 'an astonishing number of colourful formalities' in which the famous drum majorettes played their part before the appearance of the teams. At half-time there was a memorable exhibition of drill by the 
Honour Guard from Heidelberg who conducted at a quick step with rifle drill that could only 'be described as juggling ... a truly remarkable performance.' Newsreel footage the following week emphasised the 'girl cheerleaders', close-ups of the ferocious action, and the enthusiastic crowd of $20,000 .^{36}$

The prevalence of American service personnel and the continued preponderance of American films and TV programmes resulted in millions becoming infatuated with American popular culture. A minority reviled the obsession with America.. From their vantage it felt as if the military occupation of WWII was being replaced by an occupation of the mind. However, many Britons identified with and desired the lifestyles projected at the movies and on television, the freedom of the open road, modern cities with skyscrapers, shopping malls, clean highly-automated factories and well-laid out suburbs where good-looking men and women had nice houses and luxury cars. America offered a vision that anyone could be talented and become successful, even if they were from unfashionable working-class communities. Women and girls copied American clothing and hairstyles whilst using or wanting make-up by American brands, and James Dean and Marlon Brando equally impressed young men. Popular culture depicted life as exciting, glamorous and romantic in America, and all that made life pleasurable in Britain seemed to come from the US. ${ }^{37}$

American football newsreels strengthened this view. The highlights enhanced the excitement of the action and of the crowds, including close-ups of beautiful women and glamorous celebrities. The British press began to emphasize star players. Cut-ins of the 1959 Baltimore Colts defeat of the New York Giants showed packed stands, including Vice President Richard M. Nixon, and close-ups of the Colt's dynamic quarterback, Johnny Unitas, underlining his rugged masculinity in a manner reminiscent of Western heroes, a force for good, and the prototype modern heroic quarterback. ${ }^{38}$ Some politicians 
and intellectuals believed that 'having a good time' was being emphasized rather than the necessary ethos of hard work with plain living and unsophisticated leisure, qualities now perceived by many to equate to a life of boredom and banality. Critics continued to believe that American mass culture was not only levelling down high culture but also lowering the morals of the young. Although little graphic violence or sex was portrayed through film or the TV, some developed the impression that American cities were in the thrall of gangsters and dope addicts. ${ }^{39}$

The increase in TV ownership through the 1950s and the development of nightly news broadcasts sounded the death knell for the newsreel with the result that American football faded in the consciousness of the general public. ${ }^{40}$ By the 1960 s, America was no longer the place of dreams to most Britons. Britain had been transformed into a more liberal society set in its own modern landscape whilst enjoying increased ownership of the modern conveniences of life. British popular culture garnered global admiration as America's international prestige declined. The assassination of President John Fitzgerald Kennedy and the Civil Rights Movement received widespread coverage alongside bleak TV images of urban decay. Still, the spectacular and sometimes disputed nature of American football games captured some newspaper attention. The Times, for example, reported on the battle by some University of Chicago students to enforce the 1939 ban on American football at their institution because they felt that the game was a symbol of all that was undesirable in American education, 'a brutish throwback to barbarism.' The Times noted that as Chicago was a small university, it could not organize 'a big time' college team since the public 'still demand spectacular games, with marching bands, drum-majorettes and other half-time attractions. ${ }^{41}$

\section{The Super Bowl Arrives}


Through the 1970s, the British view of America became darker as rising murder and crime rates were widely reported. The Watergate scandal exposed corruption in society's upper reaches and a new wave of films, such as Dog Day Afternoon, and TV programmes such as Starsky \& Hutch showed violence as part of everyday American life. ${ }^{42}$ Nevertheless, America still fascinated the world and its popular culture was admired and copied. In 1971, Britain's commercial network, Independent Television (ITV), telecast a 'World of Sports' programme that used Super Bowl highlights to entertain and amuse its audience between two of its featured horse races. The Super Bowl fit among other between race fillers, including archery, gymnastics, and table tennis as well as international events such as log rolling from Alberta or cliff diving from La Quebrada. ${ }^{43}$ ITV's innovation proved successful and the programme showed annual Super Bowl highlights until 1980. Awareness of the Super Bowl developed through these annual glimpses, initially through happenstance. In 1971, The Times reported that the lead news item of the morning in New York was not the safe return of Apollo 15 from the moon but an injury to Joe Namath's knee, the quarterback of the New York Jets and one of America's most glamorous sportsmen. 'Broadway Joe' illustrated how sportsmen had become international celebrities, known as much for their activities off the football field as on it. He featured in glossy magazines and his name and image regularly appeared in the newspapers, on television, and on advertising billboards. Namath helped to change the image of the American footballer from a 'beautiful physical specimen, abstemious and not noted for his intellect', to a man who was not only a Super Bowl winning quarterback but admitted liking strong drink, pretty girls, fast cars, and fast talk. ${ }^{44}$

British journalist Ian Wooldridge, was in New Orleans reporting on the Joe Frazier versus Terry Daniels world heavyweight title fight the day before Super Bowl VI. He noticed that the Super Bowl generated far more interest than the heavyweight title bout. 
Woolridge observed that the Super Bowl spectacle was 'the craziest razzamatazz event in the entire calendar of American athletic entertainment', attracting 65 million American television viewers in 1971 and generating more than 1,200,000 words cabled by the media from the stadium. ${ }^{45}$ Woolridge noticed that American football had replaced not only prize-fighting but baseball as the most passionately followed sport in the US. As soon as the Super Bowl finished President Nixon phoned the winning coach offering congratulations 'in precisely the same emotionally throaty tones that he uses for Apollo splashdowns,' Woolridge trenchantly observed. ${ }^{46}$ British correspondents noted how the interest of politicians signalled an increase in the game's importance and glamour. The Times reported on the rising passion for football sweeping America making it 'the national obsession which, however briefly, leaps across the barriers of class, race, and even sex.' Those enamoured included President Nixon who even telephoned tactical suggestions to football coaches 'more often than to his military commanders.' Indeed, military operations had code words chosen from football, such as the 1972 'Operation Linebacker' in the Vietnam War. The Times contended that the 'meticulously calculated applications of brute force and opportunism and the gladiatorial passions these arouse do reflect a uniquely American aspect of character ... The glory of the game is the soaring, artillery-shell forward pass, which in its brief grace can compensate for all the dour slogging. ${ }^{47}$ The Economist revealed that Mrs. Patricia Nixon advised football widows to watch the game themselves; if the President was called away to the phone, she regarded it 'as her duty to report to him what he had missed.' The Daily Mail's Dermot Purgavie noted that America was prepared to come to a halt for the Super Bowl, but the main philosophical question was on which side was God as both teams, Washington Redskins and Miami Dolphins, held locker-room services before a game. The Redskins also benefited from the prayers of the president. ${ }^{48}$ 
By 1974, the British newspapers had begun an annual fascination with the Super Bowl environment. Super Bowl finances especially captured interest. The Daily Mail reported that the advertising slots had been sold out in April, ten months before the game and before anybody knew who was playing. At $£ 84,000$ a minute, the lucrative deals netted Columbia Broadcasting System (CBS) £1,596,000. The Economist contemplated on the idea that television had done more for professional American football than the forward pass: 'In fact, the Super Bowl has become so attractive that advertisers who use television only occasionally paid $\$ 210,000$ a minute to put their message over in 30 million homes. ${ }^{49}$ In 1977, the Daily Mail's Anthea Disney revealed that America was in the throes of 'the Six Million Dollar Hype, otherwise known as the Super Bowl.' She argued that if Britons imagined it 'as a simple athletic event you are very wrong'. She reported on the media frenzy, the well-behaved athletes who answered the same inane questions two hundred times, the fact that there was more gambling on Super Bowl Sunday than the rest of the year combined, and the fact that researchers have concluded 'that the Super Bowl is only slightly less popular than sex.' The following year Disney focussed on the competition for catering rights and the enormous efforts required to provide for the needs of the 75,000 fans lucky enough to get tickets. ${ }^{50}$ Disney's Daily Mail colleague, Liz Hodgson, underpinned the importance of the game to America by noting that whereas 2,000 reporters covered the summit between US President Ronald Reagan and Soviet leader Mikhail Gorbachev, 2,400 were accredited to the Super Bowl, outnumbering players by a 40 to 1 ratio. ${ }^{51}$

In 1981, Super Bowl XV became the first championship spectacle transmitted live to Britain. Beamed to an audience at the Odeon Theatre in London's Leicester Square, the event drew a crowd numbering about 2,500, most of whom were Americans. ${ }^{52}$ Postgame The Times reported: 
There was a corner of Leicester Square the other night that was, for three hours at least, American. Cowboy hats, football shirts, cheerleaders, hot dogs and whooping cries were the scene as the Odeon cinema audience prepared for the Super Bowl, the United States version of the FA Cup Final ... (however) long before the end, those arrayed in green walked away from inevitable defeat and out into the reality of a cold London dawn. ${ }^{53}$

\section{The Channel 4 Years, 1982-1998}

In November 1982, Channel 4, with a remit to provide alternative programming for tastes not served by mainstream TV, began broadcasting in Great Britain. The network appointed Adrian Metcalfe the commissioning editor for sport. An experienced sportsman and a 1964 Olympic silver medallist in the 4x400 metre relay, Metcalfe had also worked in sport television production for London Weekend Television and in the US on CBS 'Sports Spectacular.' ${ }^{54}$ Metcalfe wanted to not only report on sport but surround broadcasts with the event atmosphere. If Channel 4 broadcast an event, it would be covered well and production companies would be carefully selected. ${ }^{55}$ Metcalfe admired the way US broadcasters handled NFL football and decided to emulate the American model in his new venture.

He selected Cheerleader Productions to produce the programme and purchased an NFL video and commentary package which he believed to be appealing to advertisers and the British audience. Channel 4 re-packaged NFL games into edited highlight shows accompanied by carefully selected music and vivid graphics. The remit for commercial broadcasting permitted experimentation and attracted funds from American brewing giant Anheuser-Busch to glamorize the product whilst providing a strategic marketing opportunity to develop the British taste for American football and Budweiser beer. ${ }^{56}$ Cheerleader's managing director, Derek Brandon noted: 
The televising of sport in America is simply stunning. They make it fun, they make it stylish, and they make it a family occasion. These are all things we've lost from British sport. If LWT had done American Football ... they'd have been back to the presenter in the blazer with the glass of water. ${ }^{57}$

Shortly before broadcasting began, the Economist related that more Americans watched the Super Bowl than any other TV programme and it was attracting young, affluent and well-educated fans. It noted that the three US national networks had agreed to pay the NFL $\$ 2$ billion over the next five seasons to broadcast the games because the NFL had more 'razzmatazz than baseball or basketball'. ${ }^{58}$

Channel 4 broadcast its first American football show three days after the station went on air, 5 November 1982. Early programmes included an 'idiot's guide' to the game. In the same vein, The Times added, 'to the uninitiated American football is covered with as many technical phrases as there are bits of padding on the dozens of players in each team, and the sport is as bewildering to the Englishman as cricket is to the average American'. Still, The Times remarked, 'the spectacular sport is ablaze with glittering colour, awash with deafening noise and alive with a vibrant atmosphere rarely found in an English stadium ... At times the sport is bruisingly brutal; at others as delightfully delicate.' An estimated 750,000 people watched the first 75-minute programme, more than had viewed rugby union earlier in the evening. ${ }^{59}$ The broadcast slot, across 6 p.m. on Sundays, was traditionally a TV dead spot for British youth given that the 'BBC and ITV were showing religious programs' in that time slot. American football allowed Channel 4 to corner the youth market in that broadcast slot. Up until this point, American football had been considered a 'zany' pastime which most Britons did not understand. Channel 4 would soon change that. ${ }^{60}$ 
To introduce the programme the multi-coloured Channel 4 logo morphed into a smoke-snorting American football helmet-wearing figure accompanied by the score of the 'Montagues and Capulets' from Prokofiev's Romeo and Juliet. ${ }^{61}$ Then Jeremy Isaacs, the Channel 4 CEO noted Cheerleader Productions 'gave it the works to the sound of pop hits-quarterbacks threw, wide receivers leaped, tight ends crashed, running heroes touched down for glory and bounced, signalled and postured in celebration. ${ }^{62}$ Channel 4's first season ended with a live broadcast of Super Bowl XVII and the success of the coverage increased reportage of American football across the media. The Daily Mail, previewing the National Football Conference playoff, announced that 'for the first time in ten years something really important is happening in Washington ... today at 12:30 the Redskins begin combat against their arch rivals, the Dallas Cowboys'. The correspondent noted that the American capital city was 'certifiably crazy' over the game and awash in burgundy and gold. When the Redskins won, qualifying for the Super Bowl, the London daily reported that Secretary of State George Shultz and his party had arranged a live feed of the game during their diplomatic tour of Tokyo. Commenting on the following unexpected Super Bowl win by Washington, the Economist reported that President Reagan, sporting a Redskins cap, saluted the team's heroic running back, John Riggings, by rechristening his financial policy 'Rigginomics', in an effort to restore its popular appeal. $^{63}$

In its first season Channel 4 averaged an audience of over 1 million viewers for its Sunday programme. Nearly $3 / 4$ million tuned in for the Super Bowl, which began at midnight in the British Isles. In a pre-match commentary for Super Bowl XVIII, the second to be shown live by Channel 4, The Times' Simon Barnes suggested 'American football is becoming a fact of British life, and if you are not going to a Superbowl [sic] party on Sunday night, you really aren't making it.' He knew that many people thought 
the game would not catch on because Britons 'could not understand who was doing what to whom and what the rules are. Perhaps that is no hindrance after all; as a San Francisco 49er recently remarked, half the American audiences don't really understand the rules, and we've got a few players like that as well. ${ }^{64}$ More than twenty years later, in 2007, The Guardian reminisced that people went to Super Bowl parties in the 1980s barely knowing which teams were playing, 'hadn't the foggiest notion of the rules ... stayed up to three in the morning drinking weak beer (Miller Lite, anyone?) vaguely staring at a screen'. ${ }^{65}$

By Super Bowl XVIII, Channel 4's American football telecast was regularly one of its top ten shows and also in the top ten sports shows on British TV. In August 1983, Touchdown, a British-based magazine devoted to the sport debuted. It soon sold over 25,000 copies per issue. Britons began to play as well as watch the American version of football. Over thirty British American football teams were regularly playing at that time, albeit mainly flag-football as many of the squads had no kit. ${ }^{66}$ The NFL benefitted from British interest as sales of officially licensed products rose from $£ 125,000$ in 1983-1984 to over $£ 25$ million in $1987 .{ }^{67}$ Miles Kington wrote a tongue-in-cheek commentary in The Times on why American football was attracting a growing audience in Britain. He opined that whilst American football was boring, it was less boring than rugby and enlivened by dancing girls and the interesting drawings on the players' helmets. In essence, Kington contended, the audience felt they were watching American foreign policy in action and were fairly sure that Americans were going to win for a change. ${ }^{68}$

American football remained Channel 4's sports flagship for the next ten years, but viewing figures peaked in 1986 with a weekly audience of nearly $31 / 4$ million and over $31 \frac{1}{2}$ million watching Super Bowl XX. ${ }^{69}$ The growth years coincided with English association football seemingly condemned to terminal decline following stadium tragedies at 
Bradford and Heysel that killed scores of fans, intransigent and ingrained traditions of hooliganism, and the domination of the game by tedious and dreary tactics. In addition, English football was blacked-out from TV for over four months due to arguments over rights-fees. ${ }^{70}$ Into this TV void came American football, with fun-filled features including 'cheerleaders, "Hail Marys" and sophisticated touchdown celebrations'. ${ }^{71}$ Even the stadia in which American football was played seemed universally comfortable, attractive and, usually, sun-filled, symbols of modernity compared to the decayed state of British football stadia. ${ }^{72}$

Market research for the 1985-86 and 1987-88 American football seasons identified Channel 4's audience as being affluent and principally from the middle and upper classes, as well as being predominantly male and in the younger age groups. ${ }^{73}$ As The Sunday Times observed: 'Cheerleader have clearly found the advertisers' nirvana - a young, rich and enthusiastic audience ... It's almost as if the yuppies of the world were waiting for a spectator sport they could feel was theirs - something that was at its best when watched on the small screen in the warmth of their home. ${ }^{74}$ The media continued to report the astronomical sums paid per minute of air time during the Super Bowl and in 1999 the Economist concluded that 'the Super Bowl, which attracts around 90m viewers, the largest audience of the year, is the ultimate brand-building slot, and Super Bowl advertisements are the most talked about of the year. ${ }^{75}$ However, British Channel 4 viewers could not see the much-hyped adverts unless they sought them out on the internet. $^{76}$

Super Bowl XVIII in 1984, reinforced the image of American wealth, glamour and excitement shown in programmes such as Dallas, a national obsession in Britain. It featured two university marching bands of well-scrubbed youngsters in extravagant uniforms with glittering instruments performing a stunning and fun display before Barry 
Manilow, a highly popular artist in Britain, sang the national anthem. The half-time show harkened back to a nostalgic and romantic American past through a musical 'Salute to the Superstars of the Silver Screen. ${ }^{77}$

In contrast to the razzmatazz of the Super Bowl, TV programming, newspapers and movies of the mid-1980s painted a bleak picture of the US in the British imagination, depicting cities as squalid and awash in crime fuelled by an epidemic of drug abuse. In 1985, Sue Mott of The Times broached the issue of drug problems in American sport. She revealed a litany of disturbing incidents. Tulane University players had shaved points for gambling syndicates in return for cocaine; a Pittsburgh drug trafficking ring involved baseball players; and Steve Courson of the NFL's Tampa Bay Buccaneers' estimated that 95 percent of football players had tried drugs. 'You've got to get on drugs if you want to survive,' Courson confessed. In America, Mott ventured, the athlete is perceived as a 'coke snorting, dope-pushing, steroid popping zombie, who would sell grandma and the furniture for a Porsche convertible and a spot on a television beer commercial.' She noted that evidence suggested that drugs were prevalent in sport from high school to the professionals. In 1986, Michael Binyon penned The Times report on Don Rogers, the Cleveland Browns football star, who died from a cocaine overdose. Rogers' death led to questions about the NFL Players Association protests against mandatory random testing as an invasion of privacy. Binyon depicted drug usage in American sport and society as rampant, noting that 'one in six has tried cocaine in high school ... and more than half of all crime in the United States is now related to drugs. ${ }^{78}$

Covering American football led Mott to explore not only drugs but the impact of unbridled American capitalism, a different reading of Dallas that focused on the excesses of American materialism, greed, and self-interest buttressing themes also showcased in movies such as Wall Street. Mott examined franchising problems in American sport 
following the attempt of the Philadelphia Eagles owner to move the franchise to Phoenix. She concluded her investigation with a quotation from a Brooklyn Dodgers baseball fan who was still bitter about the flight of his team to Los Angeles more than 25 years before: 'it made me realize that all sport is strictly business and to hell with the fans. ${ }^{79}$

This split view of America as either a glamorous and exciting place that rewarded individual effort or a squalid and dangerous place where the poor had no effective safety net, led to enigmatic imaginings of America as the 'land of the free' or 'the great Satan', divergent interpretations both supported by American football. ${ }^{80}$ In the Daily Mail, Dermot Purgavie in his previews of Super Bowl XX recognized the Super Bowl as a cultural rite celebrating the blessed trinity of sport, television, and free enterprise in front of America's biggest TV audience. Purgavie insisted that the trinity's importance was most clearly acknowledged by President Reagan tossing the coin via satellite from Washington where he was being inaugurated for his second presidential term. Two days later, Purgavie prodded beneath the gladiatorial armour to reveal the pain of the game to the 'journeyman' player shown in the HBO documentary Disposable Heroes. Jim Otto, a former Oakland Raiders centre, suffered from arthritis in 'every joint in his body' alongside a multitude of other health problems following thirty concussions, twenty-five broken noses, a detached retina, nine knee operations and 150 facial stitches. ${ }^{81}$

Sporting heroes had been in short supply in 1980s Britain, and the NFL and its teams made individuals available to the British press to help prospective fans identify stars and develop the narrative around the game. William 'the Refrigerator' Perry quickly became a celebrity and 'a good many citizens swooned over that dandy young Miami quarter back, Marino. ${ }^{82}$ In The Times Simon Barnes ruminated that American football stars were heroes in Britain partly because little was known about them. American football was the last refuge of the true sporting hero, and audiences got 'fiendishly 
tantalizing weekly glimpses throughout the autumn, and we know nothing whatever about them other than they play football'. American football, Barnes argued, was 'an exoticism, the rules obscure, the heroes utterly mysterious. They don't even have faces; they play masked. How doubly and trebly wonderful they are because of their mysteriousness' ${ }^{83}$

In 1986, Market and Opinion Research International (MORI), a leading social research company, found that over 60 percent of Britons would not want to live in the US if they had to live outside of the UK although they liked Americans and would like a holiday there. ${ }^{84}$ In parallel to the decline of American esteem, Channel 4's American football audience declined through the second half of the 1980s and into the 1990s. Many who had responded to the packaging and enjoyed the sport as an opportunity for 'stylistic self-expression', 'self-conscious display' and an 'ethic of fun' moved on to the next big thing. Very few Britons had taken up participating in the American variety of football, resulting in an insignificant number of people attaining a deep understanding of the game or responding to its fundamental nature. Most Britons were passive viewers 'imperfectly equipped with the specific competence needed to decipher it adequately. ${ }^{85}$ Mick Luckhurst, one of the earliest native Britons to play in the NFL as a kicker for the Atlanta Falcons, became one of Channel 4's NFL broadcast hosts after he retired from American football. Luckhurst explained the problems of meeting the needs of an audience not reared in the traditions of the game:

It is very diversified. There is a small group, $10 \%$ or less, that reads every football magazine and studies every play. Then there is a larger group that has a basic understanding and just likes the game. But I am sure that there is quite a large group that is just entertained by the very large men in crash helmets beating the junk out of each other. ${ }^{86}$ 
In 1993, control of Channel 4 passed to the Channel Four Television Corporation, which signalled a change in target audience from the fringes of society to the edges of mainstream society. American football was shunted around the schedule and viewing figures inevitably dropped further.

In the 1990s, America was often regarded with hostility through its indifference to world opinion, refusing to sign the Kyoto Climate protocol in 1997 and its unquestioning support of Israel as the rest of world sought a Palestinian state. In Britain, the Louise Woodward affair led to the impression that the US had a barbaric legal system. ${ }^{87}$ In the same period English football teams were readmitted to international competition and 'rebranded as the Premier League, brawlers were shoved from the stadiums, ratings began soaring into the global-TV-revenue stratosphere and the global-sports-league ionosphere. The NFL waned.' British American football leagues declined from a peak of six in 1987 with 166 registered teams to one league in 1999 with 30 teams. In 1998, Channel 4 dropped American football whilst acquiring the rights to domestic international (Test) cricket matches. ${ }^{88}$ British fans have continued watching live coverage of the Super Bowl and various NFL packages as other broadcasters have negotiated TV rights.

\section{American football as a reflection of America}

America and American football have been intertwined in the British imagination since the late nineteenth century. Initially when the public's only information about the game was through newspapers, the British press portrayed it as a brutal and unsportsmanlike game form evolving from a barbaric and decivilizing society. Once the game was played in Britain, reported upon by journalists who actually saw the game, and highlights were seen on newsreels, the American football transformed from an atavistic carnival into a modern spectacle. 
Over the next several decades, through two world wars, the depression, and the Cold War, Britons continued to make occasional readings of American culture through football. The game remained, however, a rare and exotic experience they encountered in an occasional newsreel clip or newspaper story. In the early 1980s television changed the equation. Channel 4's broadcasting of weekly highlights and live Super Bowls was a watershed when a significant proportion of the public came to imagine the gridiron as a slice of America, that, in the words of a reporter in The Times, was 'up there with blue jeans, skyscrapers and pecan pie; as a spectacle, a National Football League game is the distillation of a Springsteen concert, a Las Vegas review and a latter-day Gunfight at the OK Corral. Real American stuff as they say. ${ }^{89}$ The Guardian's Jim Shelley thought part of the attraction was the commentators' accents, the cool high tech space age uniforms, the referees,' 'old American faces taking no nonsense', and the players with names like Plaxico Burress. For Shelley, what ultimately makes American football 'so great is its combination of power and speed, skill and violence, but really, as with most things American, when it comes to the secret of its appeal, it's the size, its scale, the sheer monotony that makes it. ${ }^{90}$

To Simon Barnes of The Times, it was no coincidence that the press headquarters of his first Super Bowl was a 'couple of blocks away from Disneyland' as 'the Super Bowl has become the most gorgeously, sumptuously, ridiculously and splendidly vulgar overthe-top media event in the history of sport.' He cited overhearing an American observer who noted that football was like a cartoon, 'people get hit and smashed and chopped down - and then they get up and do it again.' The same man added that football brought out the worst in American society, violence and committee meetings, 'a load of guys jump on top of someone, and then hold a meeting about doing it again.' ${ }^{91}$ Barnes acknowledged that 'the Super Bowl is the America we English can understand; all shiny 
excess, violence and cosmetics. Baseball is the America that does not get on the screen; the America that people live in. The spiritual home of the Super Bowl is Disneyland; the World Series is part of the heartland of America. ${ }^{92}$

The 1986 MORI poll revealed that the majority of Britons would like to holiday in America and for several million Britons the Super Bowl has become an annual, themed one-day excursion to a mythic America. ${ }^{93}$ The trip provides multiple narratives to its British consumers, Luckhurst's ten percent watching it for the game, others watching it as theatre, perhaps reminding themselves of a previous American family holiday or anticipating one, and the majority for whom the event is about partying amidst temporary Americana at home or in a pub. Indeed, two American students at a London pub noticed the TV hosts giving viewers' advice on 'pulling sickies' at the end of the live broadcast in the early hours of Super Bowl Monday. ${ }^{94}$

What all viewers get, even if they do not understand the game or care who is playing, is that instant 'when it all works and the receiver is soaring into the air to pluck the ball from the fingertips of his marker and plunge into the end zone; this sudden explosion of perfection and grace is heart-lifting'. Simon Barnes insists that American football, for all of its nonsense, fires the imagination over the 'miracles that brilliant men can work. And isn't that really the point of sport?'95

\footnotetext{
${ }^{1}$ Anonymous letter to the editor, 'Not Cricket', The Times, 11 August, 1983, 9.

${ }^{2}$ C. Armstrong, R. Fagge and T. Lockley, 'Introduction', in C. Armstrong, R. Fagge and T. Lockley (eds), America in the British Imagination (Newcastle: Cambridge Scholars, 2007), 1-7, 2.

3 J.F. Lyons, America in the British Imagination: 1945 to the Present (New York: Palgrave Macmillan, 2013).

${ }^{4}$ Daniel Archer, 'A Voice from America to Intending Emigrants', Sheffield and Rotherham Independent, 22 March 1869, 4.

${ }^{5}$ B. Miller, "The Thousand Glassy Eyes": Britishness and American Culture in Travel Narratives and Cultural Criticism', in Armstrong et al., America in the British Imagination, 153-167; H. Bridges, 'The Robber Baron Concept in American History', Business History Review, 32, no.1 (1958), 1-13.

${ }^{6}$ V.R. Berghahn, 'The Debate on "Americanization” Among Economic and Cultural Historians', Cold War History 10, no. 1 (2010), 107-130; J.H. Wiener, The Americanization of the British Press, 1830s-1914 (Basingstoke: Palgrave Macmillan, 2011); Rudyard Kipling, From Sea to Sea: Letters of Travel (New York: Charles Scribner's Sons, 1899), 139.

7 'Football: American Football Rules Amended', Leeds Mercury, 9 April 1887, 8.
} 
8 'Football', South Wales Daily News, 23 December 1889, 7. For example 'American Football: A Heavy "Butcher's Bill”', South Wales Daily News, 7 December 1897, 7; 'American Football: Heavy Casualty List', Sheffield Evening Telegraph, 11 December 1909, 6.

9 'Amusements Across the Atlantic', Exeter and Plymouth Gazette, 25 October 1894, 2.

10 'Football', Dundee Evening Telegraph, 1 January 1895, 3.

11 'Editorial', Manchester Guardian, 20 December 1893, 5.

12 'Mr. Caspar Whitney', The Times, 1 March 1895, 13.

${ }^{13}$ H.A. Bryden, 'Football Sketches: The Game - and some Reflections', Surrey Mirror, 6 December 1901, 7.

14 'American College Football', Sunderland Daily Echo and Shipping Gazette, 14 May 1910, 6; 'American Football Player's Death', The Times, 16 November 1910, 22.

15 'American Football: Game at Crystal Palace', Dundee Evening Telegraph, 21 November 1910, 4.

16 'American Football in London', London Daily News, 23 November 1910, 10.

17 'The American Game: Not an Improvement on the British Rugby Code', London Daily News, 25 November 1910, 8.

18 'American Football: Match at the Crystal Palace', The Times, 25 November 1910, 23.

19 'Americans at Weymouth', London Daily News, 25 November 1910, 8; 'American Football: The Battleships Idaho and Connecticut', The Times, 5 December 1910, 20.

20 'American Football Match', Sheffield Independent, 18 November 1915, 6.

21 'American Football: Interesting Game at Chelsea', The Times, 29 November 1918, 3; 'Hospital Cup Final Replay: The American Football Game', Liverpool Echo, 27 November 1918, 4.

${ }^{22}$ British Pathé, 'An American Cup Tie', http://www.britishpathe.com/video/an-american-cuptie/query/American+Football (accessed 29 August 2016); "Blinkhorns" Picture House', Banbury Guardian, 25 April 1918, 8; S. Hanson, From Silent Screen to Multi-Screen: A History of Cinema Exhibition in Britain since 1896 (Manchester: Manchester University Press, 2007).

23 'American Football', The Times, 27 November 1933, 5; 'The American Cheer Leaders Get to Work', Yorkshire Evening Post, 2 December 1924, 6; 'Sports in Brief', The Times, 2 December 1935, 5; E.J.

Sampson, 'American Football: How it Strikes a Visitor to the States', Yorkshire Post and Leeds Intelligencer, 3 December 1929, 6.

${ }^{24}$ Luke McKernan, 'A History of the British Newsreels' bufvc.ac.uk/wpcontent/media/2009/06/newsreels_long_history.pdf (accessed 27 August 2016).

${ }^{25}$ British Pathé, 'Some Game', http://www.britishpathe.com/video/somegame/query/American+Football; British Pathé, 'Notre Dame Whips Army Eleven 7-0', http://www.britishpathe.com/video/notre-dame-whips-army-eleven-7-0/query/American+Football (accessed 29 August 2016); British Pathé , 'Excitement ... 100\%!', http://www.britishpathe.com/video/excitement-100/query/American+Football (accessed 28 August 2016).

${ }^{26}$ A search for '"American football"', 1920-1940' on British Pathé brings up 64 films, http://www.britishpathe.com/search/query/american+football (accessed 28 August 2016).

27 J. Richards, The Age of the Dream Palace: Cinema and Society in Britain 1930-1939 (London: Routledge and Kegan Paul, 1984); G.A. Atkinson, 'British Films Made to Please America', Daily Express, 18 March $1927,6$.

${ }^{28}$ Hanson, From Silent Screen to Multi-Screen.

${ }^{29}$ Armstrong et al., 'Introduction'.

${ }^{30}$ British Pathé, 'The Tournament of Roses - The Rose Bowl', http://www.britishpathe.com/video/thetournament-of-roses-the-rose-bowl-game/query/American+Football (accessed 28 August 2016).

31 'American Football: A Match to be Played at the White City', The Times, 22 April 1943, 2; 'American Football: Saturday's Game at the White City', The Times, 4 May 1943, 2; 'American Football: Today's Match at the White City', The Times, 8 May 1943, 2; 'American Football: Match at the White City', The Times, 10 May 1943, 2.

32 'American Football at the White City', The Times, 14 February 1944, 2; 'Americans Take "Coffee Bowl"; Whip Canadians, 18-0, Overseas', The Gazette (Montreal), 20 March 1944, 18.

33 J.V. Stalin, 'Speech Delivered at a Meeting of Voters of the Stalin Electoral District, Moscow', 9 February 1946 (Moscow: Foreign Languages Publishing House, 1950); Churchill's 'Iron Curtain' Speech, https://www.youtube.com/watch?v=S2PUIQpAEAQ (accessed 20 August 2016).

${ }^{34}$ A search for '"American football"', 1945-1980' on British Pathé brings up 29 films, http://www.britishpathe.com/search/query/american+football (accessed 28 August 2016). 
35 American Football Final at Wembley', The Times, 28 November 1952, 12.
36 'American Football: An Unusual Final at Wembley', The Times, 13 December 1952, 4; 'Eagles Outplay Bullets: American Football at Wembley', The Times, 15 December 1952, 2; British Pathé, 'Wembley -US Air Force Football Final Aka ...', http://www.britishpathe.com/video/wembley-us-air-force-football-final-akaamerican/query/American+Football (accessed 28 August 2016).

${ }^{37}$ Lyons, America in the British Imagination.

38 'Colts Real "Giant Killers", http://www.britishpathe.com/video/american-football-league-baltimore-vnew-york/query/American+football (accessed 1 September 2016).

${ }^{39}$ Lyons, America in the British Imagination.

${ }^{40}$ McKernan, 'A History of the British Newsreels'.

41 'Reports from America: Football versus Greek at the University', The Times, 3 December 1963, 11.

42 Lyons, America in the British Imagination.

43 'Broadcasting Saturday', The Times, 23 January 1971, 16.

${ }^{44}$ Michael Leapman, 'Calamity of Joe's Knee is the Talk of New York', The Times, 9 August 1971, $1 \& 4$.

${ }^{45}$ Ian Wooldridge, 'What Makes Millionaires Breaks Marriages and Blows a Mind or Two?'Daily Mail, 14 January 1972, 26; Ian Wooldridge, "I Looked for the End of the Rainbow ... This was Just the End." Daily Mail, 18 January 1972, 22.

${ }^{46}$ Ian Wooldridge, ‘Our Great and Glorious Game hasn't Reached First Base Yet ... and Probably Never Will', Daily Mail, 21 January 1972, 26.

${ }^{47}$ Fred Emery, 'The Cowboys' Turn to Bite Dust', The Times, 2 January 1973, 5.

48 'Football Crazy'. Economist, 20 January 1973, 26; Dermot Purgavie, 'Quite Divine, these Dolphins and Redskins', Daily Mail, 9 January 1973, 2.

${ }^{49}$ Dermot Purgavie, 'The Wonderful Wizard isn't What He Was', Daily Mail, 4 January 1974, 2; 'Football Hooked Up', Economist, 19 January 1974, 51-52.

${ }^{50}$ Anthea Disney, 'The Next Best Thing to Love', Daily Mail, 7 January 1977, 2; Anthea Disney, 'Feeding of the 75,000', Daily Mail, 10 January 1978, 4.

${ }^{51}$ Liz Hodgson, 'Dermot Purgavie's America', Daily Mail, 23 January 1986, 13.

52 'American Football', The Times, 13 January 1981, 10.

${ }^{53}$ Stuart Jones, 'American Football: The Night the Eagles Played like Sparrows', The Times, 27 January 1981, 10.

${ }^{54}$ Peter Catterall, 'Introduction', in Peter Catterall (ed.) The Making of Channel 4, London: Frank Cass, xvxix; Dorothy Hobson, Channel 4: The Early Years and the Jeremy Isaacs Legacy (London: I.B.Tauris, 2008). ${ }^{55}$ Paul Harrison, 'Channel 4 Plans for a Jaded Audience: Playing Loudly in a Minor Key', The Times, 10 November 1982.

56 J. Maguire, 'More Than a Sporting Touchdown: The Making of American Football in England 1982-1990', Sociology of Sport Journal 7, (1990), 213-237; J. Maguire, 'The Consumption of American Football in British Society', Sport in Society 14, no. 7-8 (2011), 950-964.

57 Jennifer Selway, 'A Whole New Ball Game', Observer, 5 October 1986, 38.

58 'Fun - and Some Games', Economist, 11 September 1982, 38.

${ }^{59}$ Stuart Jones, 'The Warlords of Thunder Arrive', The Times, 14 December 1982, 22.

${ }^{60}$ Maguire, 'More Than a Sporting Touchdown', 225; Catterall, 'Introduction', ix-x.

${ }^{61}$ https://www.youtube.com/watch?v=cyyHRoQyly4 (accessed 28 July 2016).

62 Jeremy Isaacs, Channel 4 CEO, cited by Welsh Gaz forum.nfluk.com, 29 December 2009, (accessed 28 July 2016). See http://www.youtube.com/watch?v=cOxnS0zZT8c

${ }^{63}$ Dermot Purgavie, 'Redskins on the Warpath', Daily Mail, 22 January, 1983, 4; Dermot Purgavie, 'Game for a Laugh', Daily Mail, 29 January 1983, 4; 'The Triumph of Rigginomics', Economist, 5 February 1983, 46. ${ }^{64}$ Simon Barnes, 'American Football in Britain: Crash! Pow! Wow!', The Times, 20 January 1984, 8.

65 'Return of Hail Marys, Late Nights and Weak Beer', The Guardian, 4 February 2007, https://www.theguardian.com/sport/2007/feb/04/ussport (accessed 24 September 2016).

${ }^{66}$ Barnes, 'American Football in Britain'. For overviews of British American football see N. Richards Touchdown UK: American Football: Before, During and After Britain's Golden Decade (Milton Keynes: AuthorHouse, 2009); Lacey Elaine Wismer, 'British American Football: National Identity, Cultural Specificity and Globalization' (PhD thesis, Brunel University, London, 2011).

${ }^{67}$ Maguire, 'More Than a Sporting Touchdown, 228.

68 Miles Kington, 'Moreover', The Times, 25 January 1984, 10. 
69 'Punctured Football', Economist. However Selway, 'A Whole New Ball Game' cited the Super Bowl XX audience as 6.5 million.

${ }^{70}$ Simon Hart, 'Remember the 1985 TV Blackout', Independent, August 14, 2010.

71 'Return of Hail Marys', Guardian.

72 Jeff Powell, 'Where are Our Cathedrals of Sport?' Daily Mail, 31 January 1990, 6.

73 Maguire, 'The Consumption of American Football in British Society'.

74 'Punctured Football', Economist; Sunday Times, 18 January 1987, 49.

75 'Super Bowl, Super Ads, Supercostly', Economist, 28 January 1984, 70; 'Old Media's Internet Boom', Economist, 22 May 1999, 105.

${ }^{76}$ Interview with Bob Mullins, Channel 4 Regional Sales Controller (retired), 1 September, 2016.

${ }^{77}$ http://www.nfl.com/superbowl/history/entertainment (accessed 2 September 2016).

78 Sue Mott, 'Sport in America: Baseball Chief sets out to Restore some Broken Images', The Times, 22 May 1985, 28; Michael Binyon, 'US Shaken by Death of Athletes', The Times, 10 July 1986, 12.

${ }^{79}$ Sue Mott, 'Sport in America: Land of the Franchise and Home to No One', The Times, 19 December 1984, 19.

${ }^{80}$ Armstrong et al., 'Introduction', 7.

${ }^{81}$ Dermot Purgavie, 'Letter from America', Daily Mail, 14 January 1985, 8; Dermot Purgavie, 'A Question of Love', Daily Mail, 16 January 1985, 8.

82 Chuck Culpepper, 'Many Britons stuck in the ' 80 s when it comes to NFL', Los Angeles Times, 24 October 2007, http://articles.latimes.com/2007/oct/24/sports/sp-britain24 (accessed 29 August 2016).

${ }^{83}$ Simon Barnes, 'Dolphin Relaxes in Goldfish Bowl', The Times, 26 April 1986, 36.

${ }^{84}$ Lyons, America in the British Imagination.

${ }^{85}$ Pierre Bourdieu, Distinction: A social Critique of the Judgement of Taste (Cambridge: Harvard University Press, 1984); Barrie Houlihan, 'Sport and Globalization'. In Barrie Houlihan (ed) Sport and Society (London: Sage, 2008), 553-574; M. Oriard, Brand NFL: Making \& Selling America's Favorite Sport (Chapel Hill: The University of North Carolina Press, 2007); Pierre Bourdieu, 'Sport and Social Class', Social Science Information, 17, no. 6 (1978), 819-840, 829.

86 'Punctured Football', Economist.

${ }^{87}$ Louise Woodward was a 19 year old British au pair who was convicted of the manslaughter of a baby in her care in Massachusetts. Much of the debate revolved around her use of the word 'popped' which means different things in Britain and America. Later forensic evidence showed that most of the baby's injuries had occurred before Woodward arrived in the US.

${ }^{88}$ Culpepper, 'Many Britons stuck in the '80s when it comes to NFL'; Wismer, 'British American Football'; Channel Four Television Corporation: Report and Financial Statements 1998 (London: Channel Four Television, 1999), 17.

${ }^{89}$ Robert Kirley, 'Behind the Gridiron Curtain', The Times, 8 August 1987, 34.

90 'Jim Shelley's World of Sport', The Guardian, 25 January 2003, D9.

${ }^{91}$ Simon Barnes, 'Giants Rule in a Wonderful World of Make Believe', The Times, 27 January 1987, 35.

92 Simon Barnes, 'An Occasion to Stir the Hearts of all Americans', The Times, 20 October 1987, 44.

${ }^{93}$ Lyons, America in the British Imagination.

${ }^{94}$ Christopher R. Martin and Jimmie L. Reeves 'The Whole World Isn't Watching (But We Thought They Were): The Super Bowl and United States Solipsism' Culture, Sport, Society 4, no. 2 (2001), 213-236, 214; Valerie Morgan and Abbey Tingle 'A Cultural Phenomenon: Watching the Super Bowl in the UK' J. School Magazine, Missouri School of Journalism, June 2014.

${ }^{95}$ Simon Barnes, 'Violent but a Giant of a Game', The Times, 4 February 1988, 40. 